\title{
Storage Reduction of Mujeb Dam Reservoir in Jordan due to Sedimentation
}

\author{
Abbas Z. Ijam ${ }^{1} \quad$ Aseel N. Al-Nawiseh ${ }^{2} \quad$ Khaldon Ktishat $^{3}$ \\ Civil and En. Engr. Dep./ Mutah University/ Mutah/ Jordan \\ 1 Professor of Civil Engineering \\ 2 Water and En. Engineer, 3 Associate Professor of Civil Engr
}

\begin{abstract}
The flow of water from the watershed upstream of a reservoir is capable of eroding the drainage area and of depositing material either upstream of the reservoir or in the still water of the reservoir causing reservoir sedimentation. The impact of reservoir sedimentation is reducing the storage capacity, decreasing ability to produce hydroelectric power and shortening of the life of the reservoir. In the present work, Al-Mujeb dam has been selected to estimate the quantity of sediment that reaches its reservoir using the modified universal soil loss model (MUSLE). Calibration and verification were carried out using measured data for volumes of runoff and cumulative sediment yields obtained from Eco-Sounder device. The quantities of sediment yield have been predicted for the next decade, when the reservoir storage capacity will be reduced by $23 \%$. Strategies are recommended to update the Eco-Sounder measurements then the prediction process for another decade of time, and to reduce the soil erosion and minimize the sedimentation in the reservoir.
\end{abstract}

Keywords: Sedimentation, Yield, Dams, Reservoir, Erosion, Soil Loss, Storage, Jordan.

DOI: $10.7176 / \mathrm{JEES} / 10-6-10$

Publication date:June $30^{\text {th }} 2020$

\section{Introduction}

Management of water resources is a key issue facing the national government authorities in Jordan. The national water strategy is a comprehensive set of guidelines employing a dual approach of water demand management and water supply management. It places particular emphasis on the needs for improved water resources management, stressing the sustainability of present and future uses.

Dams have a common problem which is sediment accumulation in the reservoir and if these deposits are not cleared out, the reservoir will become blocked in as soon as a few decades. To meet this problem many methods were developed to measure the amount of sediment and to reduce its quantity. A supplementary method is needed to predict sedimentation in an easy and inexpensive way and to help interpreting the bathymetric surveys results. This may be possible by modeling the catchment area of dam reservoir by using modified universal soil loss equation (MUSLE).

A number of research studies have been developed all-around the world during the last twenty years in order to estimate, analyze or predict runoff, soil erosion, and sediment yield.

References $[1,2,3,4,5,6,7,8]$ are valuable studies on soil erosion and sedimentation in areas outside Jordan.

In Jordan, a number of studies conducted and focused on erosion and sediment problems. Gharaibeh [9] investigated the distribution of sediment in King Talal reservoir and the factors affecting the volume of sediment in the reservoir. Shraideh [10] estimated the sediment yield at Amman-Zerqa basin based on agricultural non-point source (AGNPS) model in order to enhance the reservoir capacity of King Talal dam reservoir. Malkawi et al [11] implemented remote sensing and GIS-assisted modeling of soil induced erosion hazards on Amman-Zerqa basin, and it was concluded that areas in the central and western parts have the highest erosion potential. Al Ansari [12] investigated the nature of sediment and its accumulation in Wadi Al-Arab dam reservoir through the analysis of sediment samples and by constructing a new bathymetric map for the reservoir, the results showed that sand mainly covers the bed of the reservoir (80.5\%) with (19.5\%) silt and clay. Ijam and Mahamid [13] estimated the quantity of sediment yield at Al-Mujeb dam reservoir during the period 2003-2006 using the Arc-View soil and water assessment tool, AVSWAT model, runoff volumes and peak flow rates are determined using rainfall measurements at stations located in the catchment area. Ijam and Tarawneh [14] investigated the sedimentation in Wala dam reservoir using the modified universal soil loss equation (MUSLE) and the soil and water assessment tool (SWAT) model. Farhan and Nawaiseh studied the annul soil loss in Wadi Al-Karak watershed using the revised universal soil loss equation (RUSLE) model, it was found the average soil loss 64 ton/hectre/year.

The present study differs from previous studies in using the MUSLE model to simulate the daily sediment yield from 6/12/2003 to 13/3/2018 using measured volumes of runoff into the reservoir. The soil erodibility factor $\left(\mathrm{K}_{\mathrm{usle}}\right)$ is determined from analysis of soil samples collected from the catchment area, and the topographic factor (LS) is estimated using the geographic information system (GIS) and ArcGIS 10.3 software. In the present work measured accumulation of sediment in the reservoir are used for calibration and verification. The measured sediments using Eco-Sounder device are obtained from the Directorate of Dams in Jordan. 


\section{Methodology}

The following steps are implemented in the present work:

1. Collecting measured data from Directorate of Dams/ Ministry of water and irrigation/ Jordan. These include, reservoir inflow, outflow and accumulated sediment yield in Al-Mujeb dam reservoir.

2. Collecting soil samples from different locations in the catchment area. Tests are performed on these samples according to ASTM specifications to estimate the erodibility factor $\left(\mathrm{K}_{\mathrm{usle}}\right)$ and the coarse fragment factor (CFRG) for the catchment area.

3. Estimate the topographic factor (LS) and the time of concentration ( $t_{c}$ ) for the catchment area using ArcGIS 10.3 software.

4. Carry out calibration process to estimate the cover and management factor $\left(\mathrm{C}_{\mathrm{usle}}\right)$ using the measured sediment in the reservoir.

5. Verification and prediction processes are performed.

\section{The Study Area}

Al-Mujeb basin forms territory around 7\% of Jordan area, and consists mainly of two main valleys Wadi AlMujeb and Wadi Al-Wala with an area of 4800 and $2200 \mathrm{~km}^{2}$, respectively. Al-Mujeb dam was constructed for municipal and industrial supply and irrigation with storage capacity of 31.2 MCM. Al-Mujeb dam catchment area is $1311 \mathrm{~km}^{2}$ lying between the desert highway and the King Highway. Al-Mujeb basin is semi-arid to arid with low rainfall in most parts of the basin in winter. The average amount of rainfall varies from $400 \mathrm{~mm} / \mathrm{year}$ in the mountainous area to $100 \mathrm{~mm} /$ year. The south western region of the catchment has elevation ranged between 900 $1200 \mathrm{~m}$ above mean sea level, decreasing in the south eastern to 600-900 $\mathrm{m}$, while the northern parts ranged from $600-1000 \mathrm{~m}$, and decreasing to 200-300 m near the dam site according to the contour map of the area shown in Figure (1).

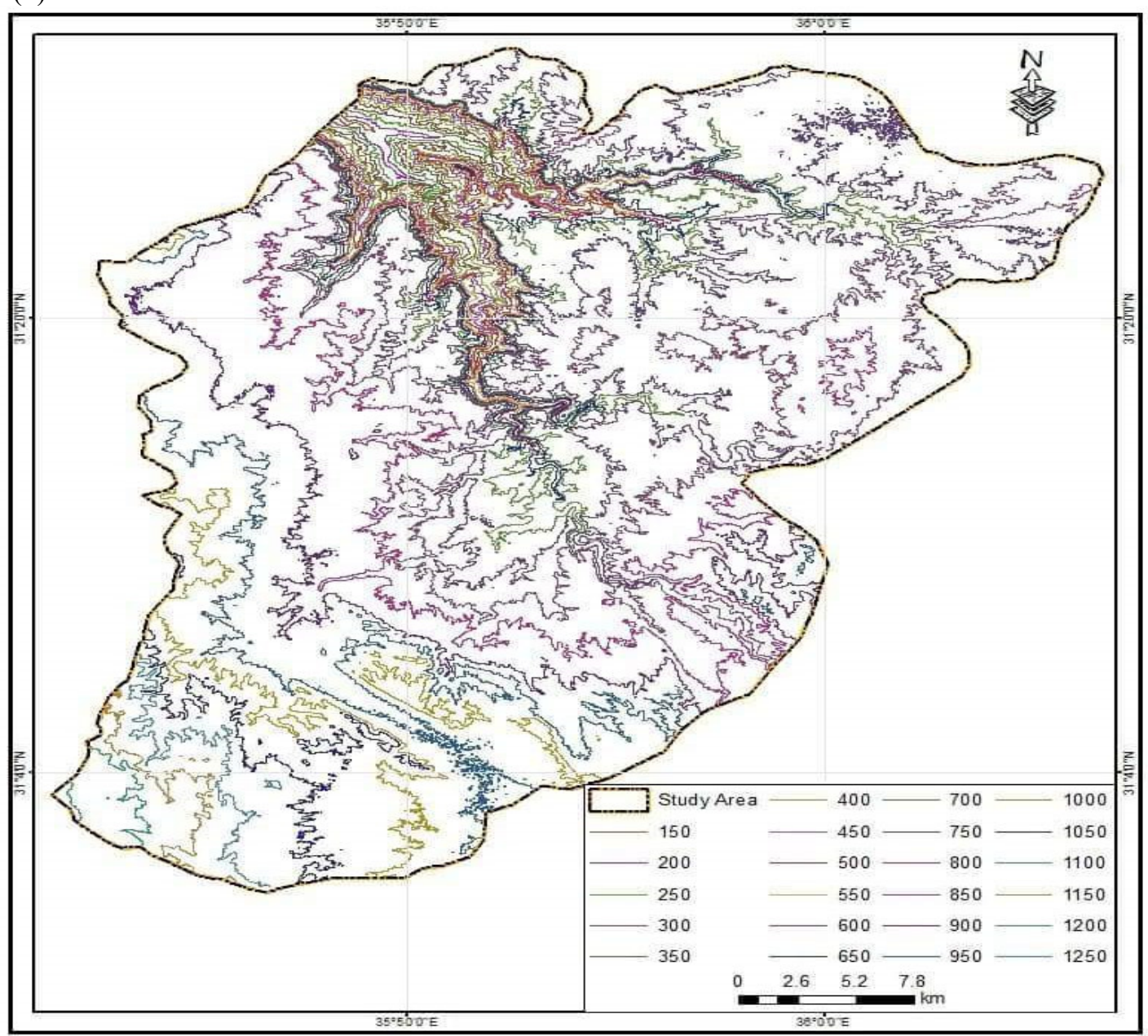

Figure 1. Contour Map for Mujeb Dam Catchment Area

\section{Sediment Yield Estimation}

The modified universal soil loss equation (MUSLE) is used in the present work, the equation was developed to 
relate empirically storm period sediment yield to upland soil loss rates indexed by universal soil loss equation (USLE), Renard et al. [15]. The MUSLE model equation is:

Sed. $=11.8\left(Q_{\text {surf }} \text {. qpeak . A }\right)^{0.56}$. K. C. P. LS. CFRAG

Where;

Sed.: Sediment yield (metric ton)

Q surf: Surface Runoff volume ( $\mathrm{mm} / \mathrm{ha})$

qpeak: The peak runoff rate $(\mathrm{m} 3 / \mathrm{s})$

$\mathrm{A}$ : is the area of the region (ha)

$\mathrm{K}$ : is the soil erodibility factor $(0.013$ metric ton $\mathrm{m} 2 \mathrm{hr} /(\mathrm{m} 3-\mathrm{metric}$ ton $\mathrm{cm}))$

$\mathrm{C}$ : The cover and management factor

P: The USLE support practice factor

LS: The USLE topographic factor

CFRG: The coarse fragment factor

The factors in equation (1) can be divided into:

- Hydrological factors like surface runoff, peak flow rate, time of concentration, runoff coefficient and rainfall intensity.

- Physical characteristics of the catchment area factors like the soil erodibility, the cover and management, the support practice, the topographic, and the coarse fragment factor.

\section{Simulation Parameters and Factors}

The present work requires the estimation of a number of parameters and factors.

5.1 Surface Runoff and Peak Flow Rates

The surface runoff is obtained from measured data obtained from the Directorate of Dams/ Jordan Valley Authority/ Jordan as a daily volume of runoff into Al-Mujeb dam reservoir for the period 6/11/2003 to 13/3/2018. The peak runoff rate is the maximum runoff flow rate that occurs with a given rainfall event, it is an indicator of the erosive power of a storm and is used to predict sediment loss, Neitsch et al, [16]. The equation for peak flow rate given in soil and water assessment tool model (SWAT) [17] is used in the present study;

$\mathrm{q}_{\text {peak }}=\frac{\text { Area } * \mathrm{Q}_{\text {surf. }}}{\mathrm{T}_{\mathrm{c}} * 3.6}$

Where;

qpeak: the peak runoff rate for the catchment area $\left(\mathrm{m}^{3} / \mathrm{s}\right)$

Area: Al-Mujeb catchment area $\left(\mathrm{Km}^{2}\right)$

$\mathrm{Q}_{\text {surf: }}$ : the measured runoff in $(\mathrm{mm})$.

3.6: is a unit conversion factor

$\mathrm{T}_{\mathrm{c}}$ : the time of concentration (hr), estimate using equation (3),

$\mathrm{T}_{\text {lag }}=0.6 \mathrm{~T}_{\mathrm{c}}$

where, $\mathrm{T}_{\text {lag }}$ is the lag time in hours. The lag time is determined by using the SCS formula;

$$
\mathrm{T}_{\text {lag }}=\frac{(\mathrm{L} * 3.28 * 1000)^{0.8} *\left(\frac{1000}{\mathrm{CN} a \mathrm{aw}}-9\right)^{0.7}}{1900 * \mathrm{Y}^{0.5}}
$$

Where;

$T_{\text {lag: lag time in hours }}$

$\mathrm{L}$ : Hydraulic length of the catchment in $\mathrm{Km}$;

$\mathrm{CN}_{\text {aw }}$ : Weighted Curve Number;

Y: average catchment slope in percents.

The parameters in equation (4) are obtained by employing ArcGIS 10.3 software, for the catchment area the average slope is $6.3 \%$, the hydraulic length is $79.3 \mathrm{~km}$. The average curve number for the area is 89.07 as determined by Al-Mahameed [18]. Use these values in equations (3) and (4), the lag time and concentration time are 7.9 and 13.15 hrs respectively.

\subsection{Soil Erodibility Factor}

Soil erodibility is a complex property and thought of as the ease with which soil is detached by splash during rainfall or by surface flow or both. The following equation is used as proposed by Williams [19];

$\mathrm{K}_{\text {USLE }}=\mathrm{f}_{\text {csand }} \mathrm{f}_{\text {cl-si }} \mathrm{f}_{\text {org }} \mathrm{f}_{\text {hisand }}$

Where $\mathrm{f}_{\text {sand }}$ is a factor that gives low soil erodibility factors for soils with high coarse-sand contents and high values for soil with little sand, $\mathrm{f}_{\mathrm{cl}-\mathrm{si}}$ is a factor that gives low soil erodibility factors for soils with high clay to silt ratios, $\mathrm{f}_{\text {org }}$ is a factor that reduces soil erodibility for soils with high organic carbon content, and $\mathrm{f}_{\text {hisand }}$ is a factor that reduces soil erodibility for soils with extremely high sand. The factors are calculated:

$f_{\text {csand }}=\left(0.2+0.3 \cdot \exp \left[-0.256 . m_{s} \cdot\left(1-\frac{m_{\text {silt }}}{100}\right)\right]\right)$ 


$$
\begin{aligned}
& f_{c l-s i}=\left[\frac{m_{\text {silt }}}{m_{c}+m_{\text {silt }}}\right]^{0.3} \\
& f_{\text {org }}=\left[1-\frac{0.25 . \text { org } C}{\operatorname{org} C+\exp [3.72-2.95 . o r g C]}\right] \\
& f_{\text {hisand }}=\left[1-\frac{0.7 \cdot\left(1-\frac{m_{s}}{100}\right)}{\left(1-\frac{m_{s}}{100}\right)+\exp \left[-5.51+22.9 .\left(1-\frac{m_{s}}{100}\right)\right]}\right]
\end{aligned}
$$

Where $\mathrm{m}_{\mathrm{s}}$ is the percent sand content $(0.05-2.00 \mathrm{~mm}$ diameter particles $), \mathrm{m}_{\text {silt }}$ is the percent silt content (0.002-0.05 mm diameter particles), $\mathrm{m}_{\mathrm{c}}$ is the percent clay content $(<0.002 \mathrm{~mm}$ diameter particles, and orgC is the percent organic carbon content of the layer (\%).

Twenty one soil samples are collected from different locations in the area, and the following tests are conducted: the specific gravity, the hydrometer analysis, the sieve analysis, and the organic carbon percent. Equations (5) to (9) are used to calculate the erodibility factor for each sample, The average value, $K_{\text {usle }}=0.164$ is obtained. Based on soil classification triangle, the soil of the catchment area is silt loam to loam soil.

\subsection{The coarse Fragment Factor:}

The percent of rock in the top soil layer is estimated from the percent returned on sieve No.4 and sieve No. 10 for each soil sample and using the following equation [16]:

$\mathrm{CFRG}=\exp (-0.053 \times \%$ of rock $)$

The average magnitude of CFRG equals 0.384 for the 21 soil samples.

\subsection{The Topographic Factor (LS):}

The topographic factor (LS) is determined by employing ArcMap10.3 software and using unit stream power erosion and deposition model (USPED). The USPED is a physically based model and uses the area of upland contributing flow to any point, Pelton [20]. The details of the used steps to estimate the LS factor for Al-Mujeb catchment area are given by Alnawaiseh [21]. An average value for LS equals 132.423 was obtained.

\subsection{The Cover and Management Factor, and the Support Practice Factor:}

The land cover and management factor $(\mathrm{C})$ has been used as a calibration parameter to calibrate the MUSLE model with respect to sediment yield at Mujeb dam reservoir as discussed below. The support practice factor (P), is assumed in the present work equals 1 since no measures are practiced to reduce the land erosion of catchment area.

\section{Results and Discussions}

From the available measured data for volume and surface runoff reaching the reservoir, the peak runoff rate is determined using equation (2). The application of MUSLE equation (1), necessitates calibration process to determine the cover and management factor (C). Using different values for $\mathrm{C}$ in equation (1), and comparison is made with measured accumulate sedimentation volume in the reservoir for the periods (2003-2005), (2005-2008), (2008-2009), and (2009-2015). These four periods are used in the calibration process to get acceptable results. The sediment yield calculated using equation (1) is divided by 1.3 on assumption the average unit weight of sediment is $1.3 \mathrm{Ton} / \mathrm{m}^{3}$. Manual calibration is implemented using different cover and management $\mathrm{C}$ factor values, and finding the optimum c value to result in minimum error in comparison with the measured values. It is found that $\mathrm{C}=0.058$ results in correlation coefficient, $\mathrm{r}=0.965$ and model efficiency [22], $\mathrm{E}_{\text {model }}=0.838$. Comparison between measured and simulated sediment is shown in Figure (2).

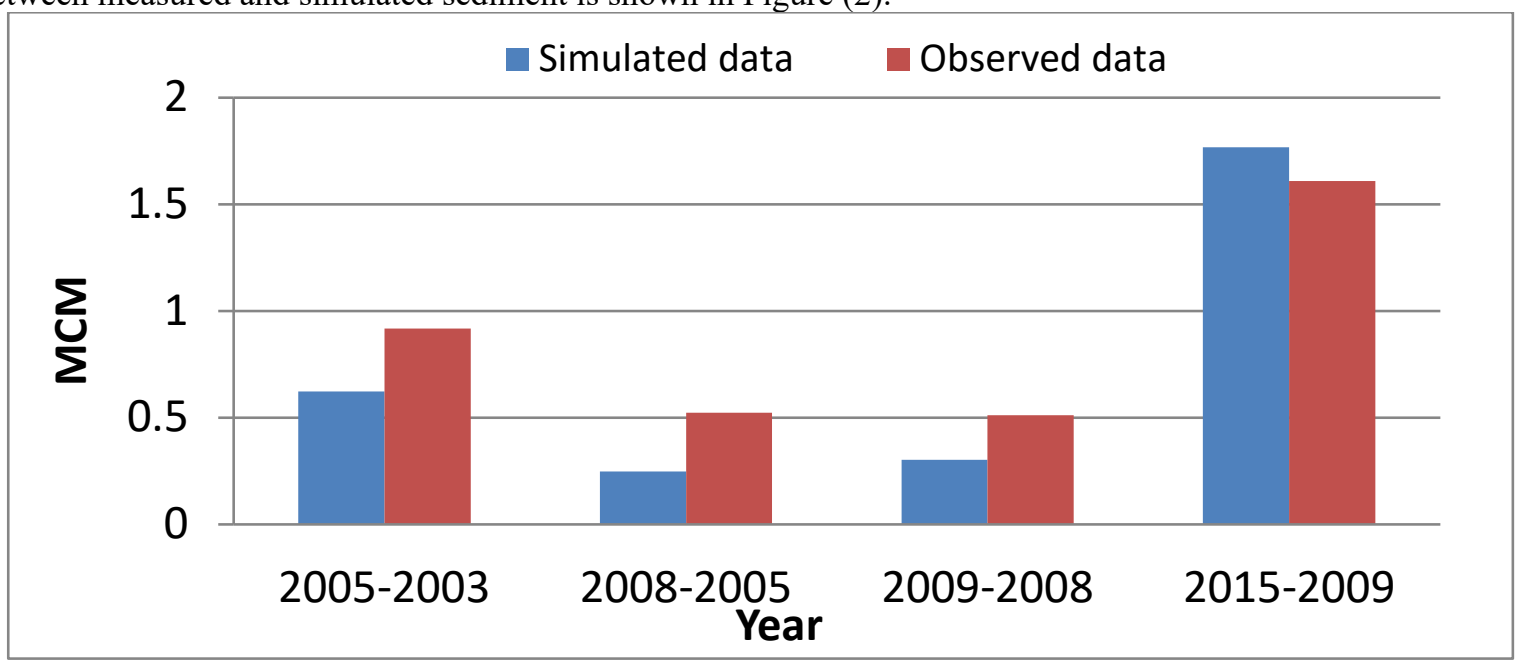

Figure 2. Comparison between the Measured and the Simulated Results 
Due to the limited measured sediment data, the verification process is introduced by redistribution the measured cumulative sediment yield according to the inflow volume in each year as a percent of the total inflow during the period of sediment measurements. Results are shown in table (1).

Table 1. The annual sediment yield

\begin{tabular}{cc}
\hline \multicolumn{2}{c}{ Table 1. The annual sediment yield } \\
\hline Year & \\
\hline 2003 & 243884.9 \\
2004 & 673938.1 \\
2005 & 324954.6 \\
2006 & 159083.2 \\
2007 & 39049.2 \\
2008 & 510166 \\
2009 & 340223.4 \\
2010 & 59665.77 \\
2011 & 139194.5 \\
2012 & 415277.7 \\
2013 & 377468.2 \\
2014 & 276178.4 \\
\hline
\end{tabular}

Good comparison is shown in Figure (3) between calculated and measured sediment yield.

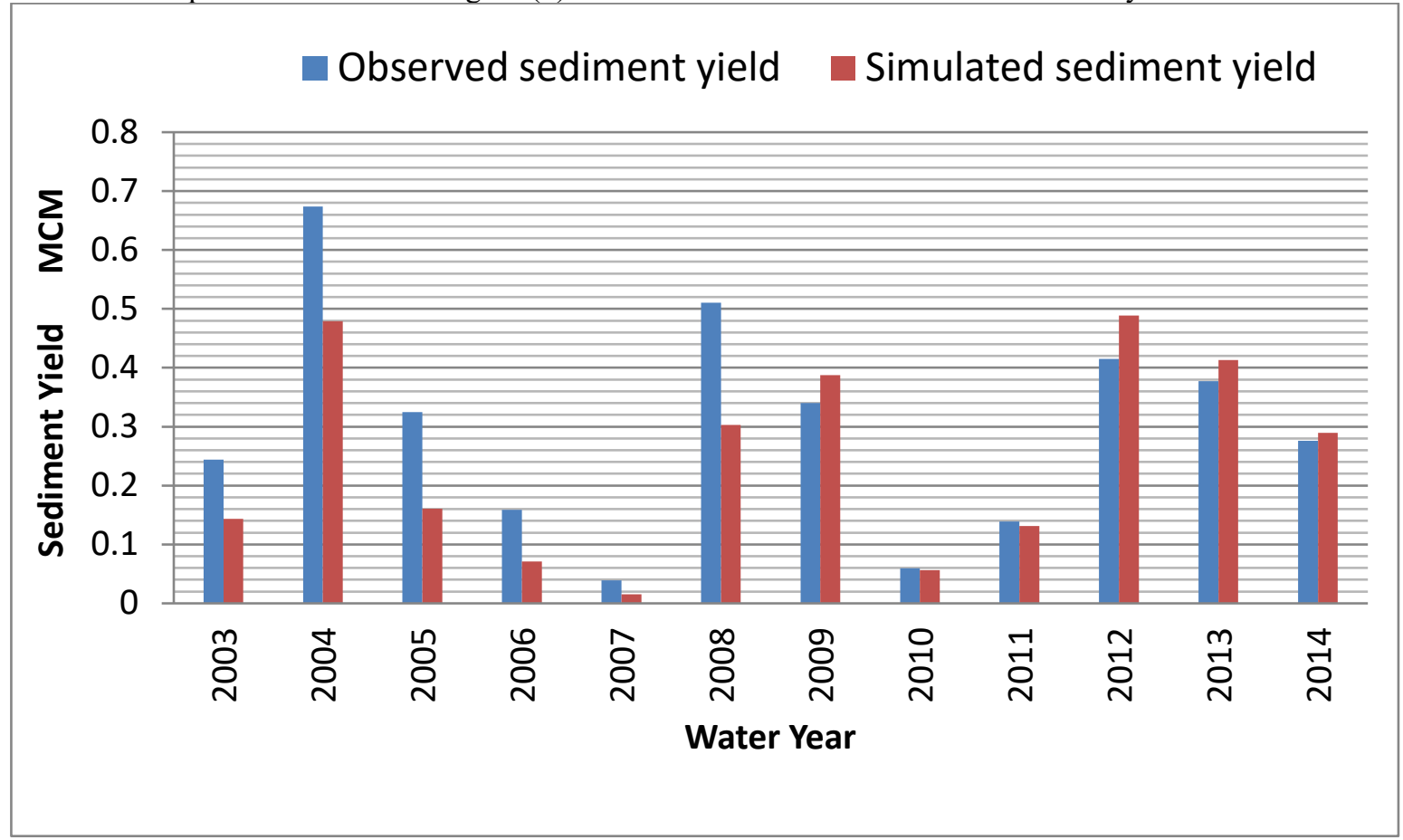

Figure 3. The Annual Simulated Sediment Yield in Comparison with Measured Sediment Yield.

The shape of variation of simulated and measured sediment yield with time is similar to that for inflow volume of surface runoff reaching the reservoir as shown in Figure (4). The sediment yield obtained from applying The MUSLE model for the years 2003-2017 with its accumulated results are shown in Table (2). Linear regression is used for the accumulated sediment results shown in Table (2), the regression line is shown in Figure (5) and its slope equals $0.262 \times 10^{6} \mathrm{~m}^{3} /$ year.

Sediment yield accumulation prediction is obtained by extrapolating the regression line shown in Figure (5).

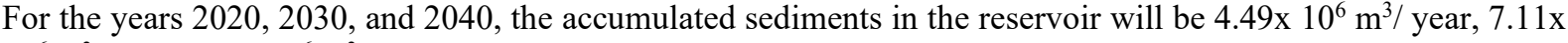
$10^{6} \mathrm{~m}^{3} /$ year, $9.73 \times 10^{6} \mathrm{~m}^{3} /$ year, respectively. This result represents reduction in reservoir storage capacity $14.39 \%$, $22.79 \%$, and $31.19 \%$, for the years 2020 , 2030, and 2040 respectively. 


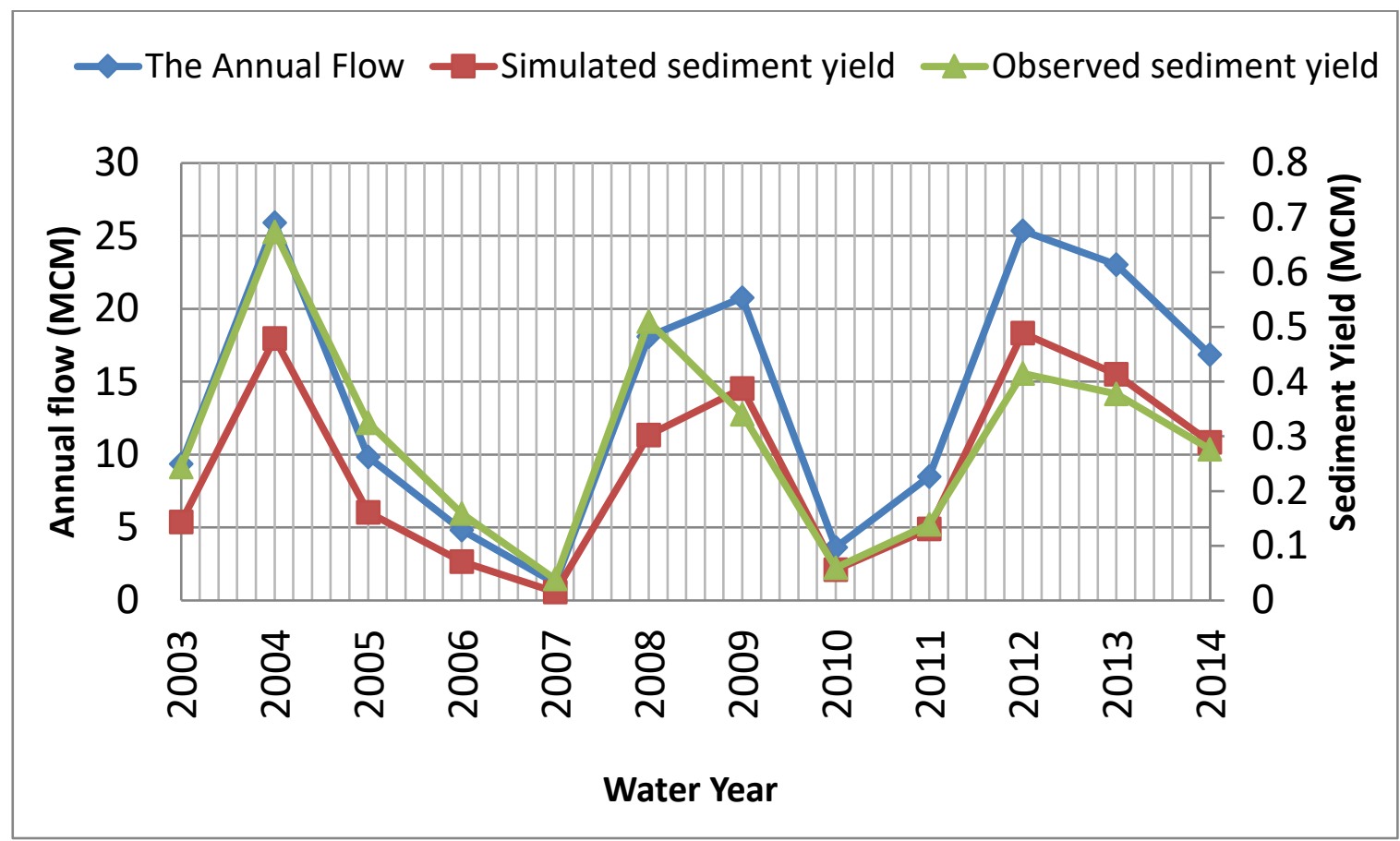

Figure 4. The Variation of Annual Surface Runoff, Measured Sediment Yield, and the Simulated Sediment Yield.

Table 2. Cumulative of simulated sediment

\begin{tabular}{ccc}
\hline Year & Annual sediment yield $\left(\mathrm{m}^{3}\right)$ & $\begin{array}{c}\text { Cumulative of simulated sediment } \\
\left(\mathrm{m}^{3}\right)\end{array}$ \\
\hline 2003 & 143243.9939 & 143243.9939 \\
2004 & 478776.6604 & 622020.6543 \\
2005 & 160980.7646 & 783001.4189 \\
2006 & 70869.77678 & 853871.1957 \\
2007 & 15504.28894 & 869375.4846 \\
2008 & 302613.0915 & 1171988.576 \\
2009 & 387748.7466 & 1559737.323 \\
2010 & 56408.71837 & 1616146.041 \\
2011 & 131061.5781 & 1747207.619 \\
2012 & 488914.516 & 2236122.135 \\
2013 & 413387.6263 & 2649509.761 \\
2014 & 289289.8581 & 2938799.62 \\
2015 & 349790.3439 & 3288589.964 \\
2016 & 258302.4986 & 3546892.462 \\
2017 & 492613.7355 & 4039506.198 \\
\hline
\end{tabular}




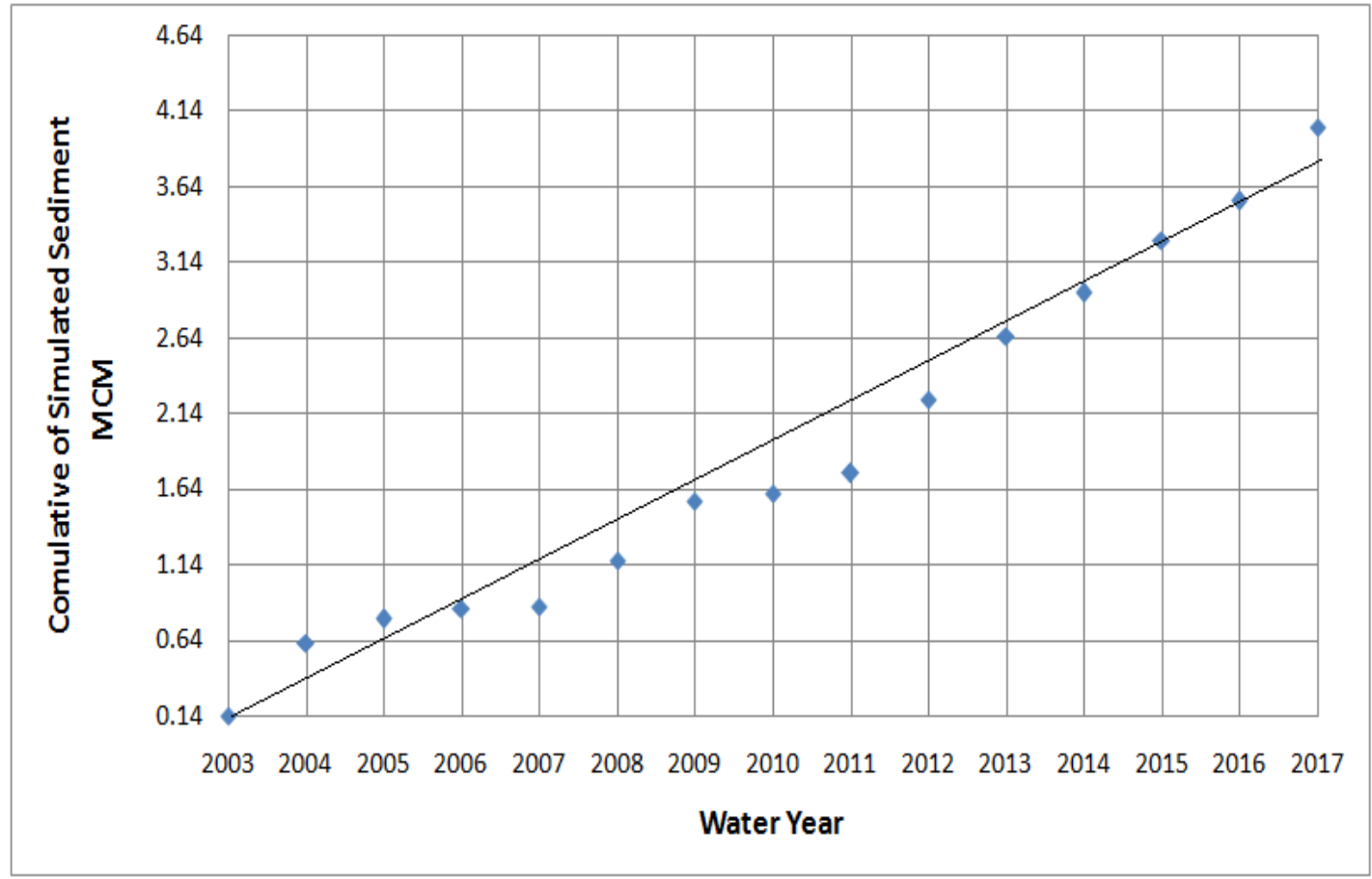

Figure 5. Regression Line for the Simulated Cumulative Sediment Yield for the Years 2003-2017

\section{Conclusions and Recommendations}

The application of the modified universal soil loss equation (MUSLE) provides a powerful tool to evaluate the land degradation and the sediment yield for a dam reservoir catchment area. Measured data are used, including volumes of surface runoff, accumulated sediment yields and soil samples from the catchment area. The cover and management factor is obtained through calibration process, $\mathrm{C}=0.058$ was obtained. Model verification successfully performed using linear regression based on proportionality between volume of runoff and sediment yield. Future sediment yield prediction is estimated and found that reduction in reservoir storage capacity due to sedimentation will be $14.39 \%, 22.79 \%$, and $31.19 \%$ in the years 2020,2030 , and 2040 respectively.

Therefore, due to the loss in storage volume caused by sedimentation, it is necessary to use periodical flushing during flood periods to minimize the amount of sediment in the reservoir, and provide the required equipment to measure the accumulated sedimentation. Management and conservation practices are recommended to be applied in the dam catchment area, including land contouring, terracing in the hilly regions and planting certain kinds of trees. Sediment traps can also be constructed, like small check dams and sediment detention basins.

\section{References}

1. Jain, Manoj K. and Kothyari, Umesh C., 2009, Estimation of Soil Erosion and Sedi- ment Yield Using GIS, Hydrological Sciences Journal, 45:5, 771-786, https://doi.org/10.1080/02626660009492376

2. Zhang, Yanli; Degroote, J.; Wolter, Calvin; and Sugumaran, Ramanathan, 2009, Integration of Modified Universal Soil Loss Equation (MUSLE) into a GIS Framework to Assess Soil Erosion Risk, Faculty Publications. Paper 37.

3. Tao Chen, Rui-qing Niu, Ping-xiang Li, Liang-pei Zhang \& Bo Du, 2010, Regional soil erosion risk mapping using RUSLE, GIS, and remote sensing: a case study in Miyun Watershed, North China, Environ Earth Sci (2011) 63:533-541

4. Demirci, Ali, Karaburun, Ahmet, 2011, Estimation of soil erosion using RUSLE in a GIS framework: a case study in the Buyukcekmece Lake watershed, northwest Turkey, Environ Earth Sci (2012) 66:903-913

5. Saleh Arekhi, Afshin Shabani \& Ghobad Rostamizad, 2011, Application of the modified universal soil loss equation(MUSLE) in prediction of sediment yield (Case study: Kengir Watershed, Iran), Arab J Geosci (2012) 5:1259-1267 .

6. Kim, Yongsik, 2014, Soil Erosion Assessment using GIS and Revised Universal Soil Loss Equation (RUSLE), CE 394K GIS in Water Resources - David R. Maidment.

7. Karl Adhar, 2016, Present and future soil erosion in the Kungsbackaån watershed, University of Gothenburg, Department of economy and society, human geography and department of earth science, 2016 B-919 .

8. Moses, Akali Ngaywa, 2017, GIS-Based Determination of RUSLE'S 'LS' Factor For River Nzoia Basin In Kenya, Masinde Muliro University of Science and Technology (MMUST), Department of Disaster 
Preparedness and Engineering Management (DPEM), https://www.researchgate.net/publication/322200080

9. Gharaibeh JQ, 1987, Prediction sedimentation in King Talal Reservoir. (M Sc Thesis), Civil Engineering Department, Yarmouk University, Irbid-Jordan.

10. Sheraideh, M. S., Malkawi, A., Hamdan, A., Abderahman, S., 2000, "Evaluation Sediment Yield at King Talal Dam Reservoir from Landslides along Irbid - Amman Highway”, Engineering Geology, No. 56, p. 361-372.

11. Malkawi, A. H. I., Saleh, B., Al-Sheridah, M., and Hamza, M., 2000, "Mapping of Landslides Hazard Zones in Jordan using Remote Sensing and GIS", ASCE Urban Planning Journal, 1: 1-17.

12. Al-Ansari, N.A. and Al-Alalami, H, 2003, Reduction of Water Storage Capacity of the Wadi Arab Dam (Jordan) due to Reservoir Sedimentation, Al Manara Journal for scientific studies and research, Volume 9, No2, 2003,pp 155-168.

13. Ijam, Abbas Z., and M. H. Mahamid, 2012, Predicting Sedimentation at Mujib Dam Reservoir in Jordan, Jordan Journal of Civil Engineering, Vol. 6, no. 4, 2012.

14. Ijam, A. Z., and E. R. Tarawneh, 2012, Assessment of Sediment Yield for Wala Dam catchment Area in Jordan, European Water, Vol. 38: 43-58.

15. Renad, K.G, Foster, G.R, Weesies, G.A, MeCool, D.K and Yoder, D.C, 1997, Predicting soil erosion by water: A Guid to conservation planning with the revised universal soil loss equation (RUSLE), United States Department of Agriculture, Agriculture hand book No.703

16. Neitsch S.L., Arnold J.G., Kiniry J.R., Williams J.R., King K.W., 2009, Soil And Water Assessment Tool Theoretical Documentation, Texas Water Resources Institute, College Station, Texas.

17. Neitsch, S.L., Arnold, J.G., Kiniry, J.R. \& Williams, J.R. 2005. Soil and Water Assessment Tool Theoretical Documentation (Version 2005). Temple, TX: USDA - ARS Grassland, Soil and Water Research Laboratory. Texas A\&M University System, Temple. Online: http://www.brc.tamus.edu/swat/ doc.html

18. Al-Mahamid .Mohammad, 2007, Predicting sedimentation at Mujeb dam reservoir, M.Sc Thesis, Department of civil engineering, Mutah university.

19. Williams, J.R., 1975. "Sediment-yield prediction with universal equation using runoff energy factor" p. $244-$ 252. In Present and prospective technology for predicting sediment yield and sources: Proceedings of the sediment yield workshop, USDA Sedimentation Lab., Oxford, MS, November 28-30, 1972. ARS-S-40.

20. Pelton. Jim , Frazier. Eli and Pikcilingis. Erin, 2014, Calculating Slope Length Factor (LS) in the Revised Universal Soil Loss Equation (RUSLE), Instruction document, Boise State University.http://gis4geomorphology.com/ls-factor-in-rusle/

21. Alnawaiseh, Aseel Nayef, Sediment Yield at Mujib Dam Reservoir in Jordan, M.Sc Thesis, Civil and Environmental Engineering Department, Mutah University, Jordan.

22. Nash, J. E. and Sutcliffe, J. V., 1970, River flow forecasting through conceptual models, Part I - A discussion of principles, J. Hydrology, 10, 282-290. 